\title{
A night heron (Ciconiiformes, Ardeidae) and a stork (Ciconiidae) from the Pliocene of Myanmar (Burma)
}

\author{
Thomas A. Stidham, Takehisa Tsubamoto, Zin-Maung-Maung-Thein, \\ Thaung-Htike, Naoko Egi, Yuichiro Nishioka, Maung-Maung, and Masanaru Takai
}

\begin{abstract}
Two new avian specimens from the Pliocene part of the Irrawaddy sediments of central Myanmar represent the youngest known fossil records of birds from Myanmar (Burma) that previously was restricted to one specimen of an ibis from the middle Eocene. The age of the Sulegon- 1 fossil locality is likely from the later part of the Pliocene based on the presence of the suid Sivachoerus prior, the anthracotheriid Merycopotamus dissimilis, and the Sumatran rhinoceros Dicerorhinus $\mathrm{sp}$. cf. D. sumatrensis. The distal tarsometatarsus is from a night heron (Ardeidae: Nycticoracini) and exhibits derived (and primitive) features consistent with night herons, but not other groups of ardeids, including the absence of a lateral deflection of trochlea III and a trochlear furrow extending to the proximal plantar end of trochlea III. The night heron fossil is not distinguishable from some species of Gorsachius and Nycticorax and may derive from one of the extant species in Southeast Asia. The other specimen (a distal tibiotarsus) represents a taxon of stork (Ciconiidae: cf. Leptoptilini) and displays many characters associated with that group (incuding a large centrally positioned intercondylar tubercle, a rounded intercondylar fossa, and distally notched trochlear rims). This stork is smaller than the 'giant' storks known from the Plio-Pleistocene of Asia and Africa, and may represent a relative of one of the large extant Asian storks. The inferred paleohabitat of the Sulegon locality as a tidal deltaic habitat is consistent with the lifestyle of both the extant night herons and large storks that occur in southeastern Asia today.
\end{abstract}

Thomas A. Stidham. Key Laboratory for Vertebrate Evolution and Human Origins, Institute of Vertebrate Paleontology and Paleoanthropology, Chinese Academy of Sciences, Beijing 100044, China.

presbyornis@gmail.com

Takehisa Tsubamoto. Graduate School of Science and Engineering, Ehime University, 2-5 Bunkyo-cho, Matsuyama, Ehime Prefecture 790-8577, Japan. tsubamoto@sci.ehime-u.ac.jp

Zin-Maung-Maung-Thein. Department of Geology, Magway University, Magway, Magway Region, Myanmar.zmmtgeo@gmail.com

Thaung-Htike. Department of Geology, University of Mandalay, Mandalay, Mandalay Region, Myanmar. thaunghtikejp@gmail.com

Naoko Egi. Primate Research Institute, Kyoto University, Inuyama, Aichi Prefecture 484-8506, Japan. egi.naoko.6z@kyoto-u.ac.jp

Stidham, Thomas A., Tsubamoto, Takehisa, Zin-Maung-Maung-Thein, Thaung-Htike, Egi, Naoko, Nishioka, Yuichiro, Maung-Maung, and Takai, Masanaru. 2016. A night heron (Ciconiiformes, Ardeidae) and a stork (Ciconiidae) from the Pliocene of Myanmar (Burma). Palaeontologia Electronica 19.2.36A: 1-12

palaeo-electronica.org/content/2016/1597-pliocene-birds-from-myanmar

Copyright: ( ) October 2016 Society of Vertebrate Paleontology. This is an open access article distributed under the terms of the Creative Commons Attribution License, which permits unrestricted use, distribution, and reproduction in any medium, provided the original author and source are credited.

creativecommons.org/licenses/by/4.0/ 
Yuichiro Nishioka. Waseda Institute for Advanced Study, Waseda University, 1-6-1 Nishi-Waseda, Shinjuku-ku, Tokyo 169-8050, Japan.nishioka@aoni.waseda.jp

Maung-Maung. Department of Geology, Loikaw University, Loikaw Township, Kayah State, Myanmar. maungmaunggeol@gmail.com

Masanaru Takai. Primate Research Institute, Kyoto University, Inuyama, Aichi Prefecture 484-8506, Japan. takai.masanaru.2s@kyoto-u.ac.jp

Keywords: Aves; Pliocene; Myanmar; Ardeidae; Ciconiidae; paleoenvironment

Submission: 26 January 2016 Acceptance: 17 August 2016

\section{INTRODUCTION}

Neogene and Pleistocene birds from South and Southeast Asia are relatively rare in the published fossil record. Recent reports of new taxa and specimens from the Pleistocene of Indonesia (Meijer et al., 2013) are beginning to fill in both a taxonomic, as well as biogeographic picture of this historically complex region, and Meijer (2014) recently reviewed the fossil record of insular portions of Southeast Asia. Prior to those new finds, rather limited published pre-Quaternary specimens from the Siwalik Hills in India and Pakistan (e.g., Davies, 1880; Harrison and Walker, 1982), the Eocene lignite mines in India (e.g., Mayr et al., 2007), the early Miocene of Thailand (Chenval et al., 1991), a single specimen from the Eocene of Myanmar (Stidham et al., 2005), the skeleton of the pelecaniform Protoplotus from Indonesia (Van Tets et al., 1989), and Oligocene avian tracks from Indonesia (Zonneveld et al., 2011) are the majority of records from the region. However, ongoing field work continues to produce Neogene and Quaternary avian material in southern Asia (e.g., Stidham et al., 2014, Forestier et al., 2015), adding to the known avian fossil material that was first published in the late nineteenth century. Despite that growing body of research, at present there remains only a single avian specimen (originally identified as an ibis relative) published from the middle Eocene of Myanmar (Burma) (Stidham et al., 2005).

Adding to that sparse record from Southern Asia (and Myanmar), we report two new avian specimens from the Pliocene of Myanmar. These new fossils record the presence of what likely are a stork (Ciconiidae) and a night heron (Ardeidae), and furthermore, those fossils may derive from species that occur in the same geographic area today. The discovery of apprarent relatives of extant birds in the Pliocene of Myanmar contrasts with that of the stragraphic sequence's mammalian fossil record (where most of the mammals known are from extinct groups, with the exception of early representatives of the Sumatran rhino), but is consistent with the Quaternary Liang Bua site in Indonesia, largely composed of extant avian taxa (Meijer et al., 2013).

The pre-Quaternary record of herons, while extending back into the Paleogene, is rather sparse (Scofield et al., 2010; Worthy et al., 2013). While some Paleogene specimens have been allocated as night herons (Scofield et al., 2010), none of those specimens are from Asia. The fossil record of pre-Quaternary ardeids in Asia includes an unnamed bittern from the Miocene of Mongolia (Zelenkov, 2011), Nyctisoma robusta from the middle Miocene of Mongolia (Elzanowski and Zelenkov, 2015), Nyctanassa kobdoena from the early Pliocene of Mongolia (Kurochkin, 1976; Zelenkov, 2013), the early Miocene Proardeola walkeri from Thailand (Cheneval et al., 1991), a Miocene indeterminate vertebral centrum from China (Hou, 1987), and the middle Miocene Ardea sytchevskayae from Mongolia (Zelenkov, 2011). Only one of those fossils is from southeastern Asia (Thailand).

Large-bodied storks are known from several sites across southern and eastern Asia in the Pliocene and Pleistocene. Traditionally, the larger storks (species of Jabiru, Ephippiorhynchus, and Leptoptilos) have been placed within Leptoptilini. However, molecular phylogenetic analyses do not consistently support the monophyly of Leptoptilini (Slikas, 1997, 1998), and a recent morphological analysis (de Pietri and Mayr, 2014) demonstrated only weak boostrap support for the group as whole. The large-bodied storks include the very large (or even 'giant') storks of Leptoptilos falconeri (Harrison, 1974; Louchart et al., 2005) from India (and elsewhere), L. robustus from Flores Island, Indonesia (Meijer and Due, 2010; Meijer et al., 2013), L. titan (Wetmore, 1940) from Java, Indonesia, and $L$. lüi from northeastern China (Zhang et al., 2012). The largest of these extinct storks have been hypothesized to stand 1.8 to 2 meters tall (Louchart et al., 2005; Meijier and Due, 2010). Some fossil 


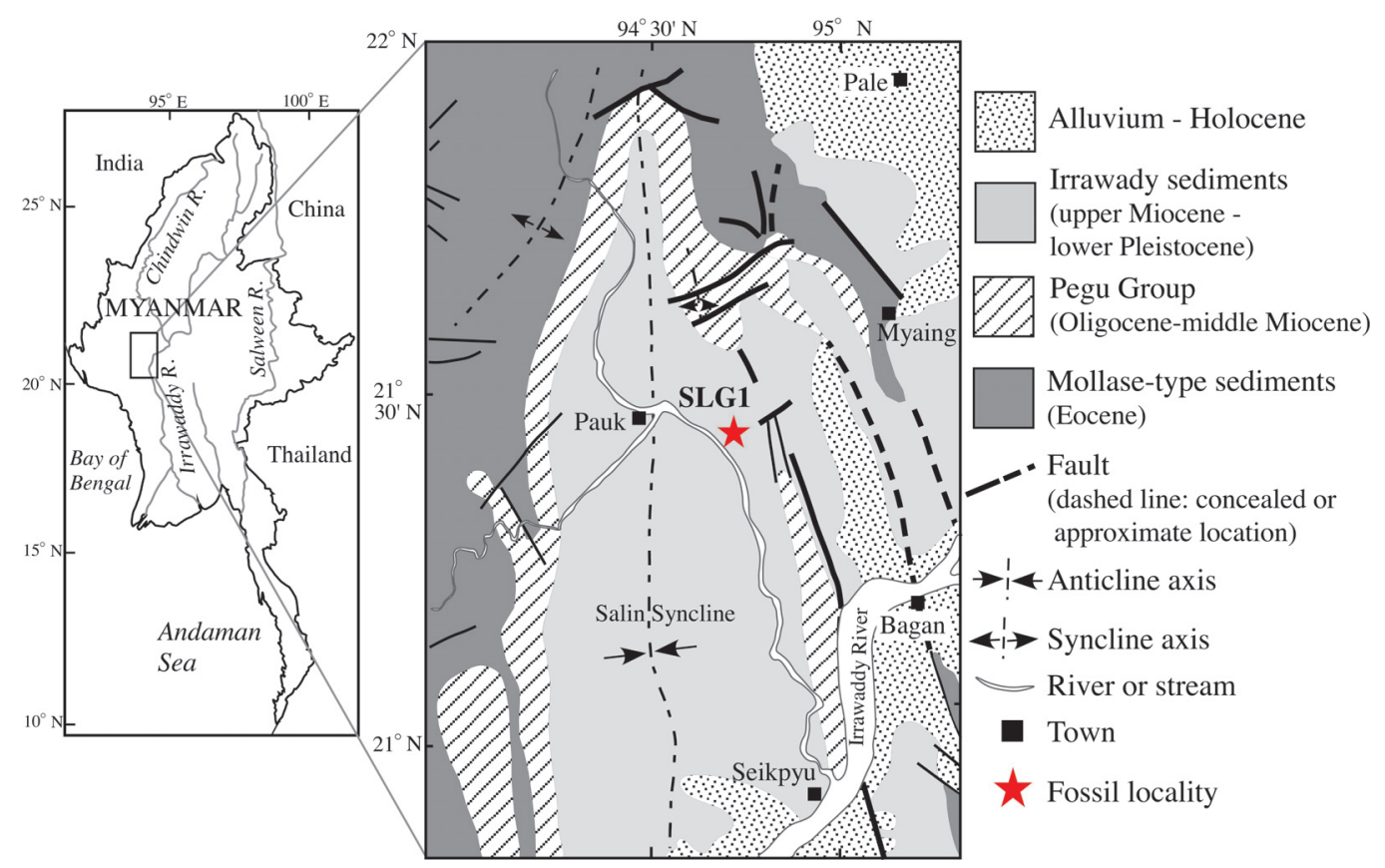

FIGURE 1. Map of Myanmar showing the SLG1 fossil locality (star) and geological map around the SLG locality (Geological map: after The Geological Map of Burma, 1: 1000,000 map; Earth Sciences Research Division, 1977).

material also has been allocated to the extant species of L. dubius (Louchart et al., 2005) from India, and two species (Ephippiorhnychus cf. asiaticus and cf. L. dubius) were identified from the Trinil site on Java (Weesie, 1982). Recently, the age of the $L$. robustus type locality was revised to an (older) age of more than 50 ka (Sutikna et al., 2016).

\section{Geological Setting}

The Neogene Irrawaddy sediments (= Fossil wood Group: Theobald, 1869; = Irrawaddian Series: Noetling, 1900; = Irrawaddy Formation: Aung-Khin and Kyaw-Win, 1969; = Irrawaddy Group: Bender, 1983) are widely distributed along the Irrawaddy River (= Ayeyarwady River) in central Myanmar (Figure 1). They are mainly composed of fluviatile sediments that are characterized by the abundance of silicified fossil woods, and the thickness has been estimated to be 2,000 to 3,000 m (Bender, 1983; Wandrey, 2006). The Irrawaddy sediments have been traditionally subdivided into the "Lower Irrawaddy" and "Upper Irrawaddy" based on the lithological and paleontological criteria (Stamp, 1922; Colbert, 1938; Bender, 1983). The Lower Irrawaddy consists of cross-bedded sandstones, gravels, and pebbly red mudstone layers with carbonate and iron concretions. The Upper Irrawaddy consists of abundant gravels and poorly consolidated sandstones with few red mudstone layers.
The geological age of the Irrawaddy sediments has been estimated by the correlation of the vertebrate faunas with those of the Siwalik Group of Indo-Pakistan. The Lower Irrawaddy has been correlated to the upper Miocene to lower Pliocene Dhok Pathan Formation of the Siwalik Group, although the base of the Lower Irrawaddy probably extends to the middle Miocene because the base yields some taxa of the Chinji Formation of the Siwalik Group (Cotter, 1938; Bender, 1983; Chavasseau et al., 2006). The Upper Irrawaddy has been conventionally correlated to the lower Pleistocene (Colbert, 1938, 1943; Bender, 1983). However, its fauna shows close resemblance to the faunas of the Tatrot and Pinjor Formations of the Siwalik Group, suggesting an upper Pliocene to lower Pleistocene correlation for the Upper Irrawaddy sediments (Zin-Maung-Maung-Thein et al., 2008).

The new bird specimens come from the Irrawaddy sediments at the SLG1 locality $\left(21^{\circ} 21^{\prime} 02 " \mathrm{~N}\right.$; 094 $\left.40^{\prime} 12^{\prime \prime} \mathrm{E}\right)$, Sulegon Village (SLG = Sulegon), Pauk Township, Magway (= Magwe) Region, western part of central Myanmar (Figure 1; Zin-Maung-Maung-Thein et al., 2010; Tsubamoto et al., 2012). Geologically, it is located in the eastern part of the N-S trending axis of the Salin Syncline (Figure 1). The upper Miocene to the lower Pleistocene massive sandstones and gravels of the Irrawaddy sediments are exposed in the central 
part, whereas the Miocene to Eocene deposits crop out in the eastern and western limbs of the syncline (Figure 1). The sediments of the syncline are estimated to be more than $9,000 \mathrm{~m}$ thick, containing lithic sandstones that alternate with the transgressive shallow marine shales (Trevena et al., 1991). The sedimentary facies and paleocurrent studies indicate a presence of north to south prograding tidal deltas (Rodolfo, 1975; Trevena et al., 1991). The SLG1 locality yielded some molluscan fossils, such as the freshwater gastropod Melannoides and freshwater bivalves Radiatula and Parreysia (Ugai et al., 2006).

The SLG1 locality has produced two bird bones, in addition to a larger sample of mammalian fossils. The Irrawaddy sediments at the SLG1 locality are assigned to the Upper Irrawaddy sediments. The sediments at the locality produced several mammalian fossils represented by indeterminate Bovidae, the suid Sivachoerus prior, the anthracotheriid Merycopotamus dissimilis, the rhinoceros Dicerorhinus sp. cf. D. sumatrensis sp., and the proboscidean Stegodon sp. (Zin-MaungMaung-Thein et al., 2010; Tsubamoto et al., 2012). This faunal assemblage has been correlated with the Tatrot and Pinjor Formations of the Siwalik Group, suggesting an age of the Pliocene to early Pleistocene (Zin-Maung-Maung-Thein et al., 2010). The presence of Sivachoerus prior potentially indicates a solely Pliocene age of this fauna (Tsubamoto et al., 2012), but Barry and others (2013) state the stratigraphic range of that species as 3.5 to $2.1 \mathrm{Ma}$, Pliocene to early Pleistocene. The stratigraphic range of the anthracotheriid Merycopotamus dissimilis in Pakistan is 7.8 - 3.3 Ma (Barry et al., 2013), and the oldest Dicerorhinus sp. cf. $D$. sumatrensis from Myanmar is thought to be approximately 3 Ma (Zin-Maung-Maung-Thein et al., 2010). Furthermore, Badgley et al. (2008) hypothesized that the Merycopotamus lineage may have survived to $2.2 \mathrm{Ma}$, as opposed to its last recorded appearance datum at $3.3 \mathrm{Ma}$. Given those various stratigraphic ranges across Asia, it would seem likley that the Sulegon-1 locality sediments and fossils derive from the later part of the Pliocene ( 3-4 Ma).

\section{Repository Information}

The designation "NMMP-KU-IR" stands for the National Museum of Myanmar Paleontology-Kyoto University-Irrawaddy. The fossil bird specimens currently are housed in Southern Branch, the National Museum and Library Department (formerly Department of Archaeology), Ministry of Cul- ture, Yangon, Myanmar. These specimens were collected by the Kyoto University (Japan) and Myanmar Government Joint Paleontological Expedition in February 2005. MVZ - Museum of Vertebrate Zoology, University of California, Berkeley, USA. NMNH - National Museum of Natural History, Washington, D.C., USA.

\section{SYSTEMATIC PALEONTOLOGY}

\author{
Order CICONIIFORMES Bonaparte, 1854 \\ Family ARDEIDAE Leach, 1820 \\ Tribe cf. NYCTICORACINI Bock, 1956
}

Figure 2

Specimen. NMMP-KU-IR 0343 is a distal tarsometatarsus.

Description. The specimen is the distal end of a right tarsometatarus broken near where the facet for metatarsal I would be positioned (Figure 2). The distal mediolateral width of the specimen is 10.1 $\mathrm{mm}$, and the mediolateral width of trochlea III is 3.1 $\mathrm{mm}$. The specimen is fractured through the shaft near its preserved midpoint, and the distal and lateral portions of trochlea IV are missing. The trochleae have a spongy appearance that could indicate a subadult ontogenetic age of this individual, or could be the result of wear or even acid etching (e.g., from the action of a carnivore's digestive system).

Trochlea II extends distal to trochlea IV, and it is much wider (mediolaterally) than trochlea IV. The area where the dorsal opening of the distal foramen should be is obscured, but the plantar opening is small and near the same proximodistal level as the proximal end of the plantar ridge extending from the base of trochlea II. The furrow on trochlea III extends from the plantar proximal end onto the dorsal surface, but the furrow does not reach the dorsal proximal end. The furrow is restricted to the plantar surface in trochlea II. Proximal to the plantar base of trochlea II is a short ridge and groove that are oriented from distomedial to proximolateral (Figure 2.5). The medial side of trochlea II is concave, and in dorsal view, the proximal end of trochlea II distinctly projects medial to the medial edge of the shaft. In distal view, trochlea III extends plantar to trochlea II, and the dorsal part of trochlea II is mediolaterally wider than its plantar portion. The lateral side of the shaft proximal to trochlea IV is relatively flat, and there is a slight ridge extending proximal from the lateral proximal base of the broken trochlea IV. The lateral intertrochlear incision is relatively shallow compared to the distal extension of the preserved part of trochlea IV. The proximal end of the specimen is near where the facet for 


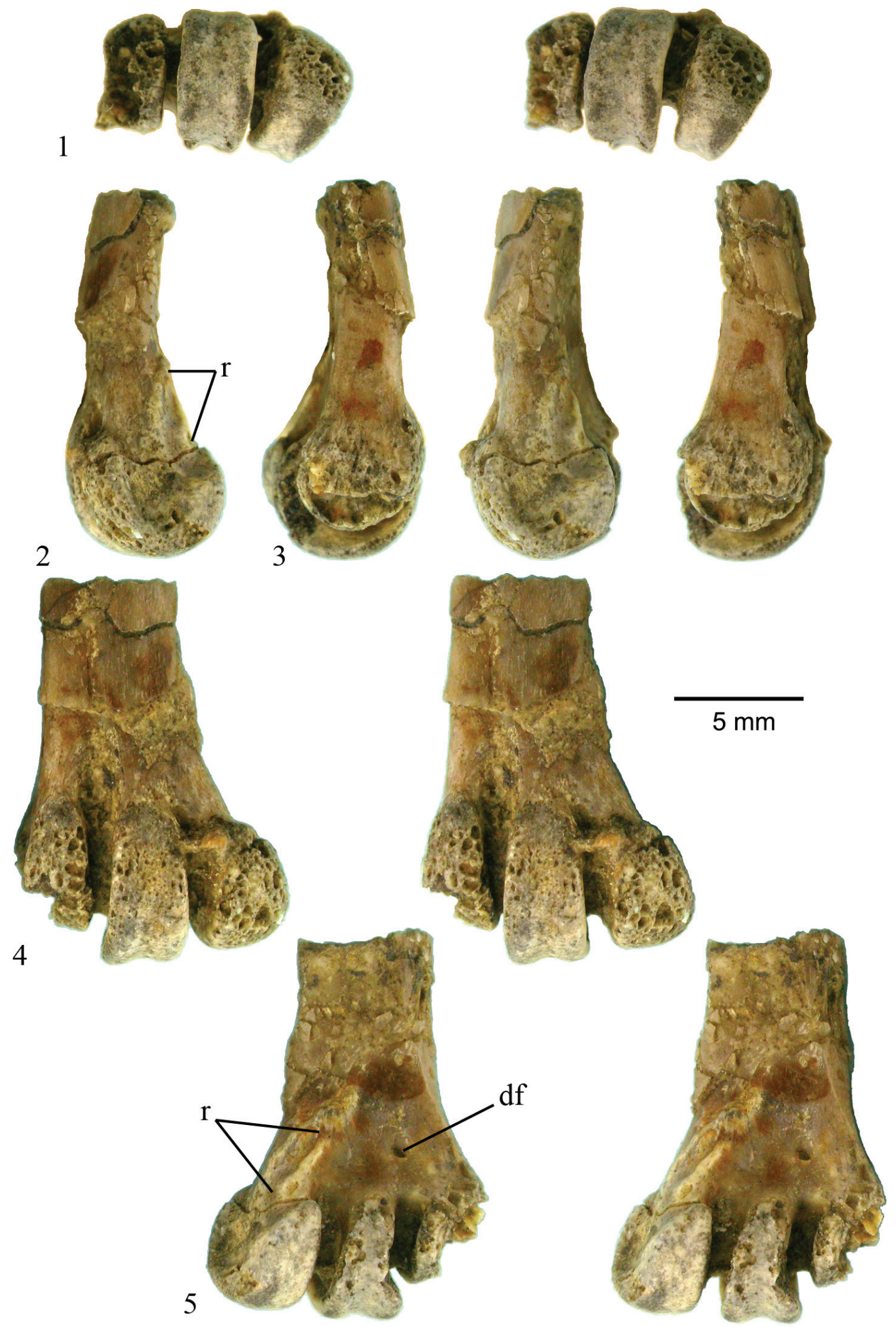

FIGURE 2. Stereophotograph pairs of the night herson distal tarsometatarsus (NMMP-KU-IR 0343) from the SLG1 locality, Myanmar. 1, distal view; 2, medial view; 3, lateral view; 4, dorsal view; 5, plantar view. Abbreviations: df - distal foramen; $r$ - ridge. 
metatarsal I would be, and it is not clear if the facet was present or not.

Comparisons. Scofield et al. (2010) and Worthy et al. (2013) utilized many tarsometatarsus characters in their analyses of fossil heron and bittern specimens. Several of these characters are present and observable in this fossil. Trochlea IV is damaged, but the preserved portion of the dorsal aspect does not preserve any evidence of a trochlear furrow (Scofield et al., 2010; Worthy et al., 2013; character 1), although a furrow may have been present in the missing portion. The trochlear furrow of trochlea III is strong all the way to its proximal plantar end (Scofield et al., 2010; Worthy et al., 2013; character 2 - state 2). That state does not occur in Ardea and Egretta (Scofield et al., 2010). The area where the dorsal opening of the distal foramen would be is obscured in the fossil (Scofield et al. 2010; character 3). The dorsal opening of the foramen is either absent or very small (states 0 or 1 ) because it likely would be visible if it was large. The obscured dorsal opening (if present) of the distal foramen means that characters 3,4 , and 5 cannot be assessed. Trochlea III is oriented in parallel with the shaft of the tarsometatarsus (Scofield et al., 2010; Worthy et al., 2013; character 6 - state 0). That state is present in Nycticorax, Nyctanassa, Pilherodius, and Tigrisoma, and absent in Ardea, Egretta, Botaurus, Ixobrychus, and Cochlearius (Scofield et al., 2010). Trochlea II protrudes abruptly (with the dorsomedial proximal edge extending distinctly medially) from the medial side of the shaft (Scofield et al., 2010; Worthy et al., 2013; character 7 - state 2). That state is present in the night herons, Pilherodius, and Tigrisoma, and is absent in other herons (Scofield et al., 2010). The plantar rim of trochlea IV is missing, and character 8 of Worthy et al. (2013) cannot be coded. Although broken, it does not appear that trochlea IV protrudes laterally beyond the shaft, or only protruded very slightly (Scofield et al., 2010; character 8 - state 0; Worthy et al., 2013; character 9 - state 0 or 1). That morphology is present in Nycticorax, Nyctanassa, Ardea ibis, Pilherodius, Botaurus, Ixobrychus, and Cochlearius, and absent in Egretta, other species of Ardea, and Tigrisoma (Scofield et al., 2010). Worthy et al. (2013) consider their version of the character as variable within night herons (i.e., states 0 and 1). The length of trochlea IV is very short distal to the intertrochlear incision relative to the width of the lateral intertrochlear incision (Worthy et al., 2013; character 10 - state 0). That state is present in night herons, Ardea, Botaurus,
Egretta, and others (Worthy et al., 2013). It is unclear if there was a facet for metatarsal I since the bone is broken near where that facet would occur (Scofield et al., 2010; character 9; Worthy et al., 2013; character 11). The area between where the metatarsal I facet and the plantar base of trochlea II appears to be relatively flat, although the bone is broken through the shaft in that area (likely state 0 of character 12 of Worthy et al., 2013). Given the published phylogenetic distribution of those characters (above), the combination of features preserved in the Sulegon fossil are consistent only with Nycticorax, Nyctanassa, and Pilherodius. Those three taxa form a clade in Scofield and coauthor's (2010) work and suggests that this fossil belongs to that clade (which includes the night herons). However, Worthy et al. (2013) did not recover a monophyletic grouping of the night herons. Instead, they form a paraphyletic stem at the base of Ardeidae (Worthy et al., 2013).

The Myanmar fossil is very similar to Nycticorax caledonicus pelewonsis and Gorsachius melanolophus. The distal mediolateral width of $N$. caledonicus pelewonsis (MVZ 95061) is 10.5/10.7 $\mathrm{mm}$ (left/right side) with a trochlea III width of 3.0 $\mathrm{mm}$ (left and right sides). That is close to the 10.1 and $3.1 \mathrm{~mm}$ equivalent measurements in the Sulegon fossil. There are no recognizable morphological differences with Gorsachius melanolophus (USNM 488330), except that the fossil is very slightly larger than the extant specimen (distal mediolateral width is $9.7 / 9.6 \mathrm{~mm}$ and trochlea III mediolateral width $5.2 / 5.3 \mathrm{~mm}$ ). With those measurements, the proportions of the trochlea III as compared to the width of the distal end appear more consistent between the Myanmar specimen and Nycticorax rather than that in Gorsachius. Nycticorax nycticorax hoatctli has a plantar end of trochlea III wider than the fossil, and the dorsal proximal end is pointed (unlike the fossil). The early Pliocene purported night heron, Nyctanassa kobdoena from Mongolia, has deeper and wider intercondylar incisions than the states in the Sulegon specimen, and its generic assignment is in question (Zelenkov, 2013). The Myanmar fossil is much bigger than Ixobrychus spp., and the second trochlea in those species is relatively smaller than the state in the fossil. Trigrisoma mexicanum (MVZ 85515 ) has a fossa around the distal foramen (dorsal side) that is much deeper than that in the fossil (no depression visible). Tigrisoma also has a ridge on the plantar base of trochlea II that is more elongate, and overall the species is larger than the fossil. The ridge proximal to the plantar side of 
trochlea II is more robust in Egretta i. intermedia (MVZ 124052) and E. novaehollandiae (MVZ 143281). In Botaurus lentiginosus (MVZ 151604), the proximal plantar end of trochlea III is very wide (vs. the more narrow condition in the fossil), and trochlea IV is projected more laterally than the fossil (also in Bulbuculus i. ibis MVZ 164538). The proximal end of trochlea III in Bulbulcus $i$. ibis is more pointed than the condition in the fossil. Butorides anthonyi (MVZ 74758) is similar in morphology to the fossil but is smaller (distal mediolateral width $7.0 \mathrm{~mm}$ ).

\section{Family CICONIIDAE Sundevall, 1836} Figure 3

Specimen. NMMP-KU-IR 0355 is a crushed left distal tibiotarsus.

Description. The specimen is crushed mediolaterally, but has a preserved mediolateral width of 18.3 $\mathrm{mm}$ (and a maximum preserved craniocaudal depth of $27.4 \mathrm{~mm}$ ). The proximal end of the ossified supratendinal bridge is obscured, and the extensor groove is not clearly visible (Figure 3 ). The lateral condyle extends proximal to the medial condyle. The intercondylar tubercle (= tuberculum ligamenti tibiometatarsale intercondylare of Smith et al. [2013] and tubercle for the attachment of ligamentum meniscotibiale intertarsi of Zinoviev [2013]) is larger and roughly in the shape of a rounded square in outline. It is clearly visible in distal view within the intercondylar incision, and the tubercle is at the same proximodistal level as the distal edge of the ossified supratendinal bridge. The tubercle projects far cranially and can be seen in lateral view extending cranial to the proximal end of the lateral condyle. The medial surface of the medial condyle is deeply concave, and there is a raised area (not quite an epicondyle) adjacent to the proximal end of the medial condyle. There is no evidence of a groove for $\mathrm{m}$. fibularis on the craniallateral corner of the shaft, but there is a short proximally directed ridge proximal and slightly lateral to the intercondylar tubercle (presumably for attachment of the extensor retinaculum). The extensor groove opens distally into the intercondylar incision (fossa), and the distal edge of the intercondylar tubercle forms part of the proximal edge of that incision (fossa). The intercondylar fossa cuts into the lateral surface of the medial condyle and appears to indent the medial side of the lateral condyle just distal to the intercondylar tubercle. The result is that the proximal end of the medial condyle appears to narrow proximally (in cranial view), while the lateral condyle extends to join with the intercondylar tubercle. The lateral condyle is deeply concave on its lateral face, and there is a low craniocaudally elongate ridge that maybe equivalent to a lateral epicondyle in that concave area. Near the craniocaudal midpoint of the distal edge of the lateral condyle is a shallow notch that extends onto the distal face of the bone. The area where a corresponding notch would be (if present) on the medial condyle is broken with a chip of bone missing. The distal face of the specimen is fractured, and bone near the center is missing. The intercondylar incision appears to have extended to the distal face, but the preserved articulation for the tibial cartilage on the caudal face is relatively flat except for a slightly concave area preserved on the medial edge. Though broken, it appears that the proximal end of the articulation for the tibial cartilage extended medially and laterally well beyond the shaft of the tibiotarsus, and that articulation's proximal end has a rounded outline. The caudal part of the preserved shaft is crushed, and it appears that some bone is also missing from the area since it is much narrower than the cranial portion (even given the crushing of the entire specimen).

Comparisons. The stork specimen shares the presence of a large centrally positioned intercondylar tubercle, large size, semi-rounded intercondylar fossa, and other features with extant (and extinct) storks. However in general, the Sulegon stork has more square profile to the intercondylar tubercle (than the more mediolaterally elongate state in many storks) and has a less pronounced medial epicondyle (than the state in many storks, see below for details). It might represent an undescribed species, but as the specimen is preserved, that cannot be definitively determined.

The stork Anastomus I. lamellaigerus (MVZ 133407 ) is much smaller than the fossil. In addition, the intercondylar tubercle is larger and more rounded than the state in the fossil. Ciconia abdimii (MVZ 133692) is much smaller than the fossil. Its medial epicondyle is much larger than the fossil, and its intercondylar tubercle is not as prominent and rounded as the state in the fossil. The lateral epicondylar fossa is deeper in the fossil than in Ciconia. Ephippiorhynchus senegalensis (MVZ 140361 ) is approximately the same size as the fossil. In cranial view, the medial condyle differs from the fossil since its proximal end is more triangular in shape/outline, and there is a pit on the proximal end of the lateral condyle that appears to be absent in the Sulegon specimen. In Jabiru mycteria (MVZ 133932), the intercondylar tubercle is more elongate, and the medial epicondyle is much larger 

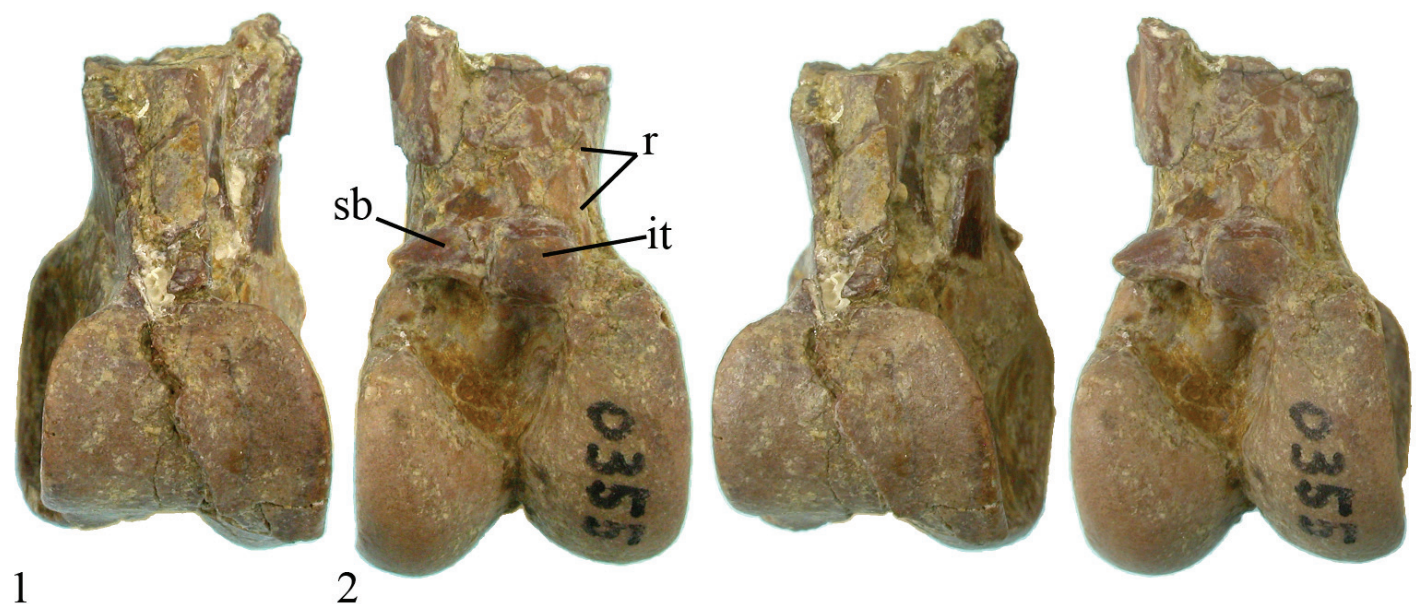

1

2

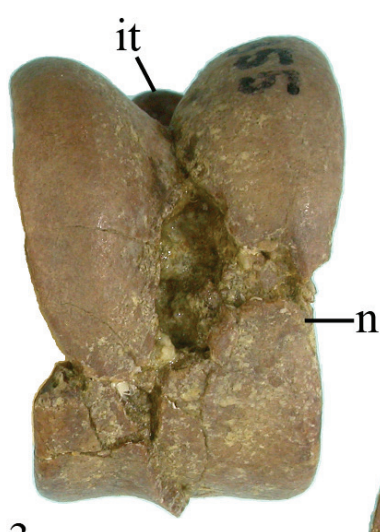

3

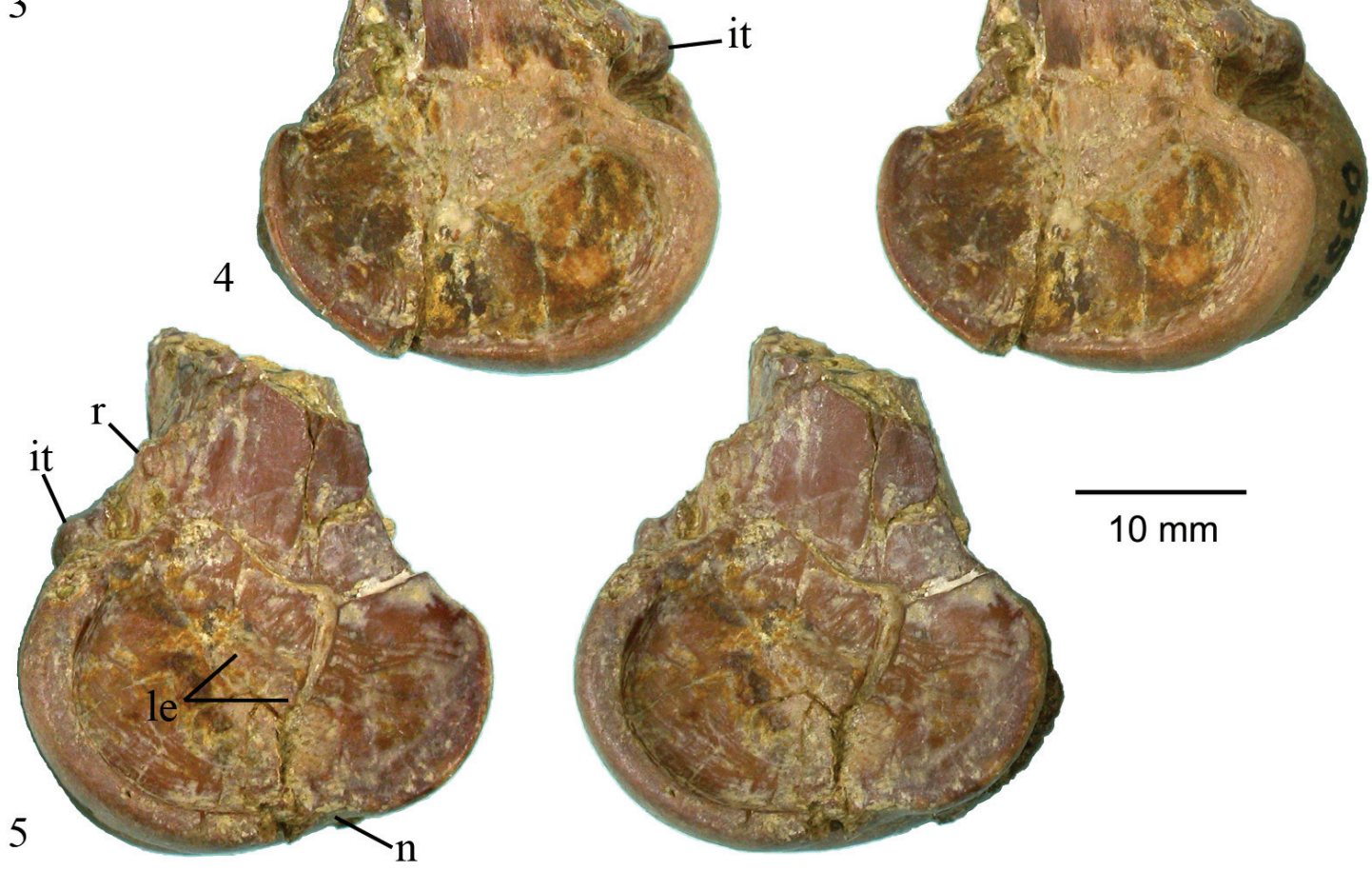

FIGURE 3. Stereophotograph pairs of the stork distal tibiotatarsus (NMMP-KU-IR 0355) from the SLG1 locality, Myanmar. 1, caudal view; 2, cranial view; 3, distal view; 4, medial view; 5, lateral view. Abbreviations: it - intercondylar tubercle; le - lateral epicondyle; $n$ - notch; $r$ - ridge; $s b$ - supratendinal bridge. 
than in the Myanmar fossil. In Leptoptilos crumeniferus (MVZ 134058), the intercondylar tubercle is more elongate, and the medial epicondyle is larger than the states in the fossil. Mycteria americana (MVZ 24920) is smaller than the Sulegon specimen, its intercondylar tubercle also is mediolaterally elongate, and the medial epicondyle is larger too.

Louchart et al. (2005) provides a thorough review of the fossil record of large-bodied storks, but that review does not illuminate any individual characters that would help to narrow the identification of this fossil specimen to species level. Furthermore, the recent phylogenetic analysis of storks by de Pietri and Mayr (2014) includes a single tibiotarsus character (the presence or absence of the intercondylar tubercle), and as a result does not aid in the taxonomic or phylogenetic placement of the Myanmar specimen within Ciconiidae.

The Myanmar specimen lacks the medial projection (cranial view) just proximal to the medial condyle that is illustrated for specimens referred to Leptoptilos falconeri from the Pliocene (Louchart et al., 2005, figure 1). That morphology results in a concave medial margin of distal end of the bone in $L$. falconeri, and there is a flat (or flatter) margin in the Myanmar specimen and L. dubius. Specimens of $L$. robustus do not preserve that region of the bone (Meijer and Due, 2010). In addition, with a larger sample size of the extant species, that character might be found to be variable, as so many other characters within stork species are variable (e.g., Louchart et al., 2005). It appears that the intercondylar tubercle is a bit more laterally positioned in the Myanmar specimen as compared to the more central position in fossil Leptoptilos (Louchart et al., 2005; Meijer and Due, 2010), but that could be the result of the mediolateral crushing that the Sulegon specimen experienced.

The (uncrushed) distal craniocaudal depth of the distal tibiotarsus is smaller in the Myanmar specimen $(27.4 \mathrm{~mm})$ than the specimens referred to $L$. falconeri (larger than $30 \mathrm{~mm}$; Louchart et al., 2005, figure 5). Overall, the Myanmar specimen is similar in size (distal depth $27.4 \mathrm{~mm}$ and distal crushed mediolateral minimum width of $18.3 \mathrm{~mm}$ ) with the extant species in Ephippiorhnychus, Leptoptilos, and Jabiru (Louchart et al., 2005, table 2). Given that the new fossil is mediolaterally crushed, the ratio of the distal depth to distal width cannot be calculated accurately (as preserved it is 1.49), and thus the ratio cannot be compared directly to that of Ephippiorhynchus and Leptoptilos (e.g., Louchart et al., 2005). Given the distal depth of the bone and a likely increase in its distal width (by $2 \mathrm{~mm}$ or so) when uncrushed, the fossil probably would fall into the Ephippiorhnychus and Leptoptilos dubius portion of the graph provided by Louchart et al. (2005, figure 5), but not into the region occupied by the 'giant' extinct storks. The Myanmar fossil is relatively close in size with the holotype of Cryptociconia indica (Harrison, 1974) that was reassigned as Leptoptilos dubius/falconeri by Louchart et al. (2005), and correspondingly appears to fall outside of the size range for the very large or 'giant' storks of the Neogene and Pleistocene (e.g., L. falconeri, $L$. titan, and L. robustus). There are no hindlimb limb bones known from $L$. lüi, and thus no comparisons can be made to the Sulegon specimen. However, given the very large size of the distal humerus in L. lüi (Zhang et al., 2012), it is very unlikely that this smaller leg bone belongs to the same species. In summary, there are no features preserved that distinctly suggest a phylogenetic position of this specimen with a particular genus group (i.e., Ephippiorhynchus or Leptoptilos), but its large size is suggestive that it belongs among the taxa placed in Leptoptilini. In addition given its smaller overall size (compared to the 'giant' storks), it is possible that the Myanmar specimen is referable or related to extant species that occur in Asia today.

\section{DISCUSSION}

The Sulegon night heron specimen (as preserved) is not readily distinguishable from that of Nycticorax caledonicus and Gorsachius melanolophus, and it is possible that the fossil derives from one of those species, other species in those genera, a currently unknown extinct species in the night heron group, or even an extinct species of Nyctanassa (a group from North America). Species of the night herons Nycticorax and Gorsachius, and the large storks Leptoptilos and Ephippiorhynchus occur in Myanmar (and more broadly in southeastern Asia) today, occupying mangrove, swamps, marshes, and wet areas in forested habitats (Robson, 2008). Given the inferred tidal delta depositional environment of the fossil-bearing sediments (above), the presence of a night heron and a stork is not unexpected in that paleoenvironment. Hopefully, future finds of large, but not 'giant' storks in southeastern Asia will aid in the reconstruction of the evolutionary history of the region's extant species, but this stork fossil demonstrates that smallersized species occurred at the same time as the very large species in southern Asia. Furthermore, the presence of relatives or members of extant lin- 
eages of birds in the Pliocene of Myanmar potentially may indicate some level avifaunal stability over the last few million years, but the story of the evolutionary history of birds in the region will be written with future avian fossils.

\section{ACKNOWLEDGMENTS}

We are grateful to Aung-Aung-Kyaw, HlaShwe, Myat-Swe, Kyaw-Myo-Win, Kyaw-Soe-Win, Zin-Oo, and other personnel of Southern Branch, the National Museum and Library Department, Ministry of Culture, Myanmar for their help in our paleontological research in Myanmar. We also wish to express our thanks to the ambassadors and staffs of the Myanmar Embassy in Tokyo and the Japan Embassy in Yangon for providing necessary assistance. $\mathrm{H}$. James provided access to modern skeletons in the $\mathrm{NMNH}$, and $\mathrm{C}$. Cicero and $\mathrm{R}$. Bowie procided access to skeletons in the MVZ. We thank N. Zelenkov and an anonymous reviewer for helpful suggestions on an earlier draft of the manuscript. T. Stidham is funded by the Chinese National Natural Science Foundation (NSFC41472025) and the Strategic Priority Research Program of the Chinese Academy of Sciences (CAS, XDB03020501). Additional financial support was provided by JSPS KAKENHI Grant Numbers 16405018, 20405015, and 26304019 (to M. Takai), and $15 \mathrm{~K} 05330$ (to N. Egi).

\section{REFERENCES}

Aung-Khin and Kyaw-Win. 1969. Geology and hydrocarbon prospects of the Burma Tertiary geosyncline, Union of Burma. Journal of Science and Technology, 2(1):52-73.

Badgley, C., Barry, J.C., Morgan, M.E., Nelson, S.V., Behrensmeyer, A.K., Cerling, T.E., and Pilbeam, D. 2008. Ecological changes in Miocene mammalian record show impact of prolonged climatic forcing. Proceedings of the National Academy of Sciences (USA), 105:12145-12149.

Barry, J.C., Behrensmeyer, A.K., Badgley, C.E., Flynn, L.J., Peltonen, H., Cheema, I.U., Pilbeam, D., Lindsay, E.H., Raza, S.M., Rajpar, A.R., and Mergan, M.E. 2013. The Neogene Siwaliks of the Potwar Plateau, Pakistan, p. 373-399. In Wang, X., Flynn, L.J., and Fortelius, M. (eds.), Fossil Mammals of Asia. Neogene Biostratigraphy and Chronology. Columbia University Press, New York.

Bender, F. 1983. Geology of Burma. Gebrüder Borntraeger, Berlin.

Bock, W. 1956. A generic review of the Family Ardeidae (Aves). American Museum Novitates, 1779:1-49.

Bonaparte, C.L. 1854. Conspectus systematics ornithologiae. Annales Des Sciences Naturelles comprenant la zoologie, la botanique, l'anatomie et la physiologie compare acutee des deux regravegnes et l'histoire des corps organisés fossiles. Rédiǵee pour la zoologie par Audouin et Milne-Edwards; pour la botanique par Ad. Brong-niart et Guillemin, Paris (Series 4), 1:105-152.

Cheneval, J., Ginsburg, L., Mourer-Chauviré, C., and Ratanasthien, B. 1991. The Miocene avifauna of the Li Mae Long locality, Thailand: systematics and paleoecology. Journal of Southeast Asian Earth Sciences, 6:117-126.

Chavasseau, O., Chaimanee, Y., Soe Thura Tun, Aung Naing Soe, Barry, C.J., Marandt, B., Suder, J., Marivaux, L., Ducrocq, S., and Jaeger, J.J. 2006. Chaungtha, a new middle Miocene mammal locality from the Irrawaddy Formation, Myanmar. Journal of Asian Earth Sciences, 28:354-362.

Colbert, E.H. 1938. Fossil mammals from Burma in the American Museum of Natural History. Bulletin of the American Museum of Natural History, 74:255-436.

Colbert, E.H. 1943. Pleistocene vertebrates collected in Burma by the American Southeast Asiatic Expedition. Transactions of the American Philosophical Society (New Series), 32:395-429.

Cotter, G.D.P. 1938. The geology of parts of the Minbu, Myingyan, Pakokku, and lower Chindwin Districts, Burma. Memoirs of the Geological Survey of India, 72(1):1-136.

Davies, W. 1880. On some fossil bird-remains from the Siwalik Hills in the British Museum. Geological Magazine, 7:18-27.

De Pietri, V.L. and Mayr, G. 2014. The phylogenetic relationships of the early Miocene stork Grallavis edwardsi, with comments on the interrelationships of living Ciconiidae (Aves). Zoologica Scripta, 43:576585.

Elzanowski, A. and Zelenkov, N.V. 2015. A primitive heron (Aves, Ardeidae) from the Miocene of Central Asia. Journal of Ornithology, 156:837-846.

Forestier, H., Sophady, H., Puaud, S., Celiberti, V., Frère, S., Zeitoun, V., Mourer-Chauviré, C., Mourer, R., Than, H., and Billault, L. 2015. The Hoabinhian from Laang Spean Cave and in its stratigraphic, chronological, typo-technilogical and environmental context (Cambodia, Battambang Province). Journal of Archeological Science: Reports, 3:194-206.

Harrison, C.O. 1974. A re-examination of material of the extinct marabou stork, Leptoptilos falconeri: with descriptions of some new species. Bulletin of the British Ornithologists' Club, 94:42-50.

Harrison, C.O. and Walker, C.A. 1982. Fossil birds from the Upper Miocene of Northern Pakistan. Tertiary Research, 4:53-69.

Hou, L. 1987. The Aragonian vertebrate fauna of Xiacaowan, Jiangsu - 6. Aves. Vertebrata Palasiatica, 25:57-68.

Kurochkin, E.N. 1976. New Data on Birds from the Pliocene of Western Mongolia, Transaction of the Joint 
Soviet-Mongolian Paleontological Expedition, 3:5167.

Leach, W.E. 1820. Eleventh Room, Upper floor, p. 65-70. In Synopsis of the Contents of the British Museum,17th edition. Cox and Baylis, London.

Louchart, A., Vignaud, P., Likius, A., Brunet, M., and White, T.D. 2005. A large extinct marabou stork in African Pliocene hominid sites, and a review of the fossil species of Leptoptilos. Acta Palaeontologica Polonica, 50:549-563.

Mayr, G., Rana, R.S., Sahni, A., and Smith, T. 2007. Oldest fossil avian remains from the Indian subcontinental plate. Current Science, 92:1266-1269.

Meijer, H.J.M. 2014. The avian fossil record in Insular Southeast Asia and its implications for avian biogeography and palaeoecology. PeerJ, 2:e295. doi:10.7717/peerj.295

Meijer, H.J.M. and Due, R.A. 2010. A new species of giant marabou (Aves: Ciconiiformes) from the Pleistocene of Liang Bua, Flores (Indonesia). Zoological Journal of the Linnean Society, 160:707-724.

Meijer, H.J.M., Sutikna, T., Saptomo, W.E., Due, R.A., Wasisto, S., James, H.F., Morwood, M.J., and Tocheri, M.W. 2013. Late Pleistocene-Holocene nonPasserine Avifauna of Liang Bua (Flores, Indonesia). Journal of Vertebrate Paleontology, 33:877-894.

Noetling, F. 1900. Tertiary system in Burma. Records of the Geological Survey of India, 28:59-86.

Robson, C. 2008. Birds of South-East Asia. Second edition. Bloomsbury Publishing, London.

Rodolfo, F. 1975. The Irrawaddy delta: Tertiary setting and modern offshore sedimentation. p. 339-356. In Broussard, M.L. (ed.), Deltas-Models for Exploration. Houston Geological Society, Houston.

Scofield, R.P., Worthy, T.H., and Tennyson, A.J.D. 2010. A heron (Aves: Ardeidae) from the early Miocene St. Bathans fauna of southern New Zealand. Records of the Australian Museum, 62:89-104.

Slikas, B. 1997. Phylogeny of the avian Family Ciconiidae (storks) based on cytochrome b sequences and DNA-DNA hybridization distances. Molecular Phylogenetics and Evolution, 8:275-300.

Slikas, B. 1998. Recognizing and testing homology of courtship displays in storks (Aves: Ciconiiformes; Ciconiidae). Evolution, 52:884-893.

Smith, N.D., Grande, L., and Clarke, J.A. 2013. A new species of Threskiornithidae-like bird (Aves, Cicconiiformes) from the Green River Formation (Eocene) of Wyoming. Journal of Vertebrate Paleontology, 33:363-381.

Stamp, L.D. 1922. An outline of Tertiary geology of Burma. Geological Magazine, 59:481-501.

Stidham, T.A., Holroyd, P.A., Gunnell, G.F., Ciochon, R.L., Tsubamoto, T., Egi, N., and Takai M. 2005. A new ibis-like bird (Aves: cf. Threskiornithidae) from the late middle Eocene of Myanmar. Contributions from the Museum of Paleontology University of Michigan, 31:179-184.
Stidham, T.A., Krishan K., Singh, B., Ghosh, A., and Patnaik, R. 2014. A pelican tarsometatarsus (Aves: Pelecanidae) from the latest Pliocene Siwaliks of India. PLoS One 9(11):e111210. doi:10.1371/journal.pone.0111210

Sundevall, C.J. 1836. Ornithologiskt System. Kungliga Svenska Vetenskapsakademiens Handlingar, 1836:43-130.

Sutikna, T., Tocheri, M.W., Morwood, M.J., Saptomo, E.W., Jatmiko, Awe, R.D., Wasisto, S., Westaway, K. E., Aubert, M., Li, B., Zhao, J., Storey, M., Alloway, B.V., Morley, M.W., Meijer, H.J.M., van den Bergh, G.D., Grün, R., Dosseto, A., Brumm, A., Jungers, W.L., and Roberts, R.G. 2016. Revised stratigraphy and chronology for Homo floresiensis at Liang Bua in Indonesia. Nature, 532:366-369.

Theobald, W. 1869. On the beds containing silicified wood in eastern Prome, British Burma. Records of the Geological Survey of India, 2(4):79-86.

Trevena, A.S., Varga, R.J., Collins, I.D. and Nu, U. 1991. Tertiary tectonics and sedimentation in the Salin (Fore-arc) basin, Myanmar. American Association of Petroleum Geologists (Annual meeting of AAPG), 75(3):683.

Tsubamoto, T., Thaung-Htike, Zin-Maung-Maung-Thein, Egi, N., Nishioka, Y., Maung-Maung, and Takai, M. 2012. New data on the Neogene anthracotheres (Mammalia, Artiodactyla) from Central Myanmar. Journal of Vertebrate Paleontology, 32:956-964.

Ugai, H., Takai, M., Tsubamoto, T., Egi, N., MaungMaung, Chit-Sein, Thaung-Htike, and Zin-MaungMaung-Thein. 2006. A preliminary report on the freshwater molluscan fossils from Myanmar. Asian Paleoprimatology, 4:205-220.

Van Tets, G.F., Rich, P.V., and Rini Marino-Hadiwardoyo, H. 1989. A reappraisal of Protoplotus beauforti from the early Tertiary of Sumatra and the basis of a new Pelecaniformes family. Publication of the Geological Research and Development Centre, Republic of Indonesia, Paleontological Series, 5:57-75.

Wandrey, C.J. 2006. Eocene to Miocene composite total petroleum system, Irrawaddy-Andaman and north Burma geologic provinces, Myanmar, Chapter E, p. 1-26. In Wandrey, C.J. (ed.), Petroleum systems and related geologic studies in Region 8, South Asia: U.S. Geological Survey Bulletin 2208-E. Reston, Virginia.

Weesie, P.D.M. 1982. The fossil bird remains in the Dubois collection, p. 87-90. In Bartstra, G.J. and Casparie, W.A. (eds.), Modern Quaternary Research in Southeast Asia, Vol. 7. A.A. Balkema, Rotterdam.

Wetmore, A. 1940. Avian remains from the Pleistocene of central Java. Journal of Paleontology, 14:447-450.

Worthy, T.H., Worthy, J.P., Tennyson, A.J.D., and Scofield, R.P. 2013. A bittern (Aves: Ardeidae) from the early Miocene of New Zealand. Paleontological Journal, 47:1331-1343.

Zelenkov, N. 2011. Ardea sytchevskayae sp. nov., a new heron species (Aves: Ardeidae) from the middle Mio- 
cene of Mongolia. Paleontological Journal, 45:572579.

Zelenkov, N. 2013. New finds and revised taxa of early Pliocene birds from Western Mongolia, p. 153-170. In Göhlich, U.B. and Kroh, A. (eds.), Paleornithological Research 2013: Proceedings of the 8th International Meeting of the Society of Avian Paleontology and Evolution, Vienna, 2012. Verlag Naturhistorisches Museum, Vienna.

Zhang, Z., Huang, Y., James, H.F. and Hou, L. 2012. A marabou (Ciconiidae: Leptoptilos) from the middle Pleistocene of Northeastern China. The Auk, 129:699-702.

Zin-Maung-Maung-Thein, Takai, M., Tsubamoto, T., Thaung-Htike, Egi, N., and Maung-Maung 2008. A new species of Dicerorhinus (Rhinocerotidae) from the Plio-Pleistocene of Myanmar. Palaeontology, 51:1419-1433.
Zin-Maung-Maung-Thein, Takai, M., Tsubamoto, T., Egi, N., Thaung-Htike, Nishimura, T. D., and MaungMaung. 2010. A review of fossil rhinoceroses from the Neogene of Myanmar with description of new specimens from the Irrawaddy Sediments. Journal of Asian Earth Sciences, 37:154-165.

Zinoviev, A.D. 2013. Notes on pelvic and hindlimb myology and syndesmology of Emeus crassus and Dinornis robustus (Aves: Dinornithiformes), p. 253-278. In Göhlich, U.B. and Kroh, A. (eds.), Paleornithological Research 2013: Proceedings of the 8th International Meeting of the Society of Avian Paleontology and Evolution, Vienna, 2012. Verlag Naturhistorisches Museum, Vienna.

Zonneveld, J.P., Zaim, Y., Rizal, Y., Ciochon, R.L., Bettis III, E.A., Aswan, and Gunnell, G.F. 2011. Oligocene shorebird footprints, Kandi, Ombilin Basin, Sumatra. Ichnos, 18:221-227. 